\title{
ANALYSIS OF THE ECONOMIC IMPACT OF CYSTIC ECHINOCOCCOSIS IN SLAUGHTERED RUMINANTS IN DUHOK PROVINCE, KURDISTAN REGION, IRAQ.
}

\author{
AZAD Abdullah MeERKhan \\ Dept. of Nursing, Duhok Technical Institute, Duhok Polytechnic University, Kurdistan Region- Iraq
}

(Received: July 28, 2019; Accepted for Publication: September 1, 2019)

\begin{abstract}
The objective of current study was to determine the prevalence of hydatidosis that is responsible for condemnation of slaughtered animals' viscera and to estimate the livestock-associated monetary losses attributable to cystic echinococcosis, in Duhok Province, Kurdistan region, northwestern Iraq and some nearby area for 8 years (2011-2018). Livestock-associated losses were estimated using data from 7 abattoirs belong to Duhok Veterinary Directorate. Between January 2011 and December 2018, 1,229,669 livestock $(852,187$ Sheep, 157,311 goats, and 220,171 cattle) were slaughtered with total infection rate of 8.04\% $(98,919 / 1,229,669 ; 95 \%$ confidence interval [CI]: $8.03 \%-8.04 \%)$; and ratios of $9.49 \%$ $(80,834 / 852,187 ;$; $95 \%$ CI: $9.45 \%-9.51 \%), 4.81 \%(7,561 / 157,311 ; 95 \%$ CI: $4.79 \%-4.84 \%)$ and $4.78 \%$ $(10,524 / 220,171 ; 95 \%$ CI: $4.76 \%-4.81 \%)$ in sheep, goats and cattle respectively. The total loss from the condemned organs was 1,218,757\$ from about 150 tons of 98,919 different organs, with the highest been in liver which was $951,568 \$$ from 90 tons of 50,461 livers then in liver $\&$ lungs together $(226,504 \$$ from 37 tons in 13,025 animals), while in lungs the loss was $34,519 \$$ from 22 tons of 34,005 lungs then from kidney $(5,048 \$$ from 0.5 ton of 1,148 kidneys) and finally the loss from spleen which was $1,117 \$$ from 0.1 ton of 280 spleen. The infected rate (condemned) liver in sheep and goats was significantly greater than other organs, while in cattle the lung was dominant organ $(53.35 \%, 53.29 \%$ and $48.25 \%$ respectively). This parasite clearly remains the most common in animal production, causing considerable economic loss in Duhok Province and, presumably, other areas of Iraq.
\end{abstract}

KEYWORD: Echinococcosis, Cystic Echinococcosis, Hydatid cysts, Economic loss, Hydatidosis, Zoonosis.

\section{INTRODUCTION}

A nimal's production play an important role in human nutrition and socio-economic development. Meat, milk, eggs and even ruminant offal are source of protein, energy, calcium and micronutrients, forming around $28 \%$ of protein and $13 \%$ of calories worldwide (Herrero and Thornton 2013). In developing countries, livestock act as a direct source of income; contribute to crop production through the provision of manure and traction power (Randolph et al. 2007). These countries have 2/3 of the livestock population in the world, but theirs meat production less than a third and a fifth of world's milk (Pradere 2014).

Hydatidosis is one of the important parasitic diseases of livestock that has both economic and public health significance. It is associated with severe morbidity and disability, and is one of the world's most geographically widespread zoonotic diseases (Kebede et al. 2009).

Cystic echinococcosis (CE), caused by the larval stage of the taeniid tapeworm Echinococcus granulosus, and considered as a public health challenge in many parts of the world. The adult parasite inhabits the small intestine of the dog which considers as a definitive host, the eggs are shed into the environment by the dog's feces. The ingestion of these eggs by the livestock and humans, the infection is occurred and then the cysts develops in the liver, lungs, or other organs (McManus 2003, Torgerson 2003).

Recently, the World Health Organization (WHO) considered $\mathrm{CE}$ in as a Neglected Tropical Diseases (NTDs) to be addressed within its 2008-2015 strategic plan for control of 
NTDs (WHO 2007 and Budke et al. 2009). Costs associated with CE have a great impact on affected individuals, their families' economy as a whole (Torgerson 2003 and Budke et al. 2006).

Cystic echinococcosis considered as a cosmopolitan zoonosis, with highly endemic areas especially South America, China, North Africa, and the Middle East (Eckert and Deplazes 2004). The CE induced production losses in ruminants are losses of offal (liver, lung, etc.), productivity losses (reduction in carcass weight, milk production and fleece value), and fertility losses (Sarı̈̈zkan and Yalçın 2009).

In some countries, the production losses due to $\mathrm{CE}$ were estimated in various species such as sheep, goats, cattle and yak. Under this concept, $\mathrm{CE}$ decreased the commercial value of infected sheep by $10 \%$ under Italian field conditions (Mantovani 1980), In China, carcass weight due to $\mathrm{CE}$ was reduced $7.2 \mathrm{~kg}$ per infected cattle, and $1.1 \mathrm{~kg}$ per infected sheep (Yang 1992). In Portugal, the estimation of the reduction in carcass weight, milk production and fleece value as $5-20 \%, 7-10 \%$ and $10-40 \%$, respectively (Houin 1998).

In Spain, (Jimenez et al. 2002) reported the reductions in carcass weight and milk production of sheep due to CE and found them 5 and 10\%, respectively. In Extremadura, Spain, the costs of condemned viscera were found at approximately $2 \%$ of the total yearly costs of CE (Battelli 2004). Monetary losses due to $\mathrm{CE}$ have been estimated for Spain (Benner et al. 2010), Uruguay (Torgerson et al. 2000), Peru (Moro et al. 2011), for a highly endemic area of the Tibetan plateau (Budke et al. 2005, Yang et al. 2010), Tunisia (Majorowski et al. 2005), Jordan (Torgerson et al. 2001) and Turkey (Sarı̈̈zkan and Yalçın 2009).

In Iraq, parasites considered as a most causative agent of the public health diseases (Hussein and Meerkhan 2019), while hydatidosis is considered as one of the most serious helminthic diseases with important socioeconomic problem, and the cost was estimated in Iraq as millions dollars (Saeed et al. 2000 and Meerkhan and Mero 2018). Its effect is due to the destruction of some animal viscera or the whole carcass, when heavily infected; also the animal milk production, wool and meat are decreased. It is most common in area where sheep/dog cycle operates and it occurs in all Iraqi provinces and territories (Saeed et al. 2000). Many epidemiological studies indicated that $\mathrm{CE}$ is endemic in Kurdistan, with high variability rates among livestock such as, sheep, goats and cattle (Ghaffar 2008, Meerkhan and Abdullah 2012, Hama 2013, AL-Bosely 2014, Hassan 2017, Meerkhan and Mero 2018).

The novelty of this study is to estimate the economic impact of all loss components of slaughtered ruminant in districts (Amedy, Mankesh, Zakho, Akry, Bardarash and Semel) and some nearby areas of (Shingal, Shekhan, Zummar and Fayda) for the period from 2011 to 2018.

\section{MATERIALS AND METHODS}

\section{Description of the study area:}

The present study was conducted from 2011 to 2018 in Duhok, Kurdistan Region, Iraq. It is a northern Province, most of the population is found in the main districts of cities of Amedy, Mankesh, Zakho, Akry, Bardarash and Semel in addition to some nearby areas of Nineveh province close to Duhok Province, were also included such as, Shingal, Shekhan, Fayda and Zummar.

\section{Data Collection:}

The data of slaughtered animals, infected organs and their infection rates were gathered from the official records of Duhok Veterinary Directorate. The prices of the different organs for each year were gathered from Duhok traditional Directorate.

\section{Economic loss estimation:}

The assessment of the direct economic loss attributed to hydatidosis was suggested by (Yemane 1990) and maintained by (Getaw, Beyene et al. 2010).

$$
\begin{aligned}
\text { Annual loss }= & \left(\mathrm{N}_{\mathrm{ps}} \times \mathrm{I}_{\mathrm{O} 1} \times \mathrm{C}_{\mathrm{O} 1}\right)+\left(\mathrm{N}_{\mathrm{ps}} \times \mathrm{I}_{\mathrm{O} 2} \times \mathrm{C}_{\mathrm{O} 2}\right) \\
& +\ldots \ldots\left(\mathrm{N}_{\mathrm{ps}} \times \mathrm{I}_{\mathrm{On}} \times \mathrm{C}_{\mathrm{On}}\right) .
\end{aligned}
$$

Where Nps: total number of positive animal slaughter, $\mathrm{I}_{\mathrm{O} 1}$ : prevalence of organ $_{1}$ hydatidosis, $\mathrm{I}_{\mathrm{O} 2}$ : prevalence of $\operatorname{organ}_{2}$ hydatidosis, Ion: prevalence of final organ hydatidosis, $\mathrm{C}_{\mathrm{O} 1}$ : cost of organ ${ }_{1}, \mathrm{C}_{\mathrm{O} 2}$ : cost of $\operatorname{organ}_{2}, \mathrm{C}_{\mathrm{On}}$ : cost of final organ. 


\section{Data analysis:}

Data analysis for the prevalence was calculated according to the proportion of the infection rates in slaughtered animals. The total losses were calculated using the weight and prices of each organ of each host.

Abattoir survey data were recorded into a MS Excel sheet, and all descriptive analyses were made using the software SPSS (version 19 for Windows). Analysis of variance was assessed to compare several groups using ANOVA according to the infected organ(s). In all tests, P. value of $<0.05$ was considered indicative of a statistically significant difference. All statistical tests were performed using SPSS 24 software.

\section{RESULTS AND DISCUSSIONS}

1. The number of slaughtered animals, infected animals and the infected rates distributed on years discussion:

From a total of 1,229,669 animals slaughtered, the overall prevalence rate was $8.04 \%$. with respect to the years $(2011,2012$, 2013, 2014, 2015, 2016, 2017 and 2018), rates of infections were $5.28 \%, 12.71 \%, 12.33 \%, 4.90 \%$, $4.96 \%, 7.95 \%, 7.92 \%$, and $7.99 \%$, respectively, with the highest rate in the year, 2012 (Figure 1).
The infection rates in different slaughtered animals were shown in the figure 1 , the highest infection rate in sheep was found in the year 2012 and the lowest infection rate was found in the year 2014 (16.51\% and $6.37 \%$ respectively) which agreed with the results published by (Meerkhan and Abdullah 2012) and (Abdullah 2010), on the other hand, they were disagreed with that published by (Meerkhan and Mero 2018) and (Singh et al. 2014), while in goats, the highest infection rate was found in the year 2017 and the lowest infection rate was found in the year 2015 ( $8.38 \%$ and $1.91 \%$ respectively).

These results agreed with the results published by (Meerkhan and Abdullah 2012) and (Abdullah 2010), on the other hand, they were disagreed with that published by (Meerkhan and Mero 2018).

Concerning cattle, the highest infection rate was found in the year 2012 and the lowest infection rate was found in the year 2014 (6.96\% and $1.36 \%$ respectively), these results agreed with the results published by (Meerkhan and Abdullah 2012) and (Abdullah 2010), on the other hand, they were disagreed with that published by (Meerkhan and Mero 2018).

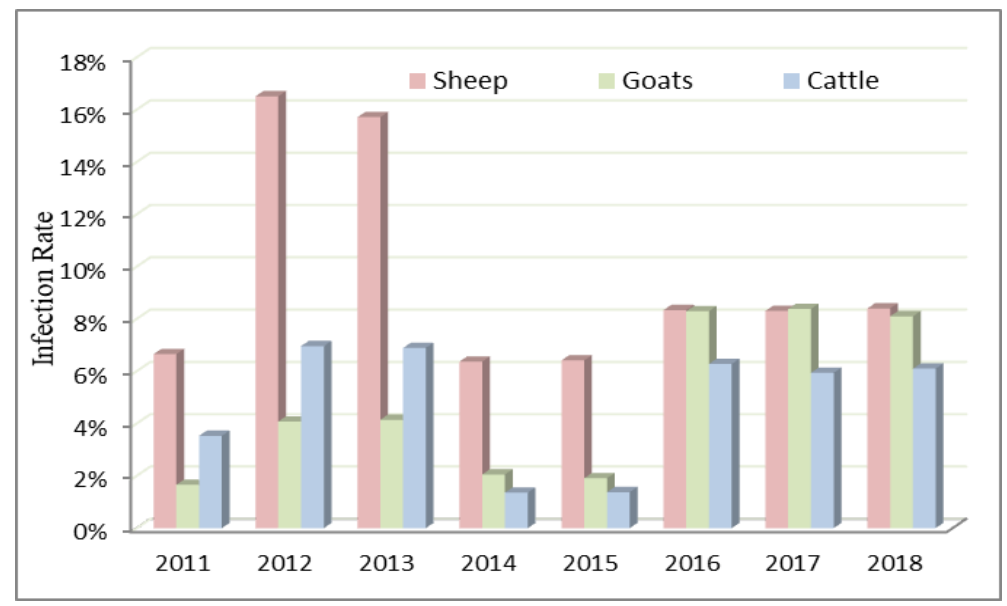

Fig (1): The infection rate of slaughtered animal over years and hosts

2. The number, the weight and the cost of slaughtered animals distributed on years:

During the eight years of this study period, the weight of the total 1,229,669 slaughtered animals and consumed by the Duhok and nearby area inhabitance was shown in table 2 and found 64,822 tons in a cost of $764,892,772$ US\$ distributed in sheep, goats and cattle (weight: 
23,676 tons, cost: $285,345,790$ US\$; weight: 4,480 tons, cost: $52,179,615$ US\$ and weight: 36,666 tons, cost: 427,367,368 US\$ respectively).

Concerning different animals, the heights weight of consumed meat of sheep and its cost was found in the year 2018 (4,127 tons in $50,333,339$ US\$), while the lowest weight and its cost was found in the year 2011 (1,702 tons in $20,615,914$ US\$), with respect to goats, the heights weight of consumed meat and its cost was found in the year 2013 (712 tons in $8,253,383$ US\$), while the lowest weight and its cost was found in the year 2011 (423 tons in 4,925,612 US\$), concerning cattle, the heights weight of consumed meat and its cost was found in the year 2015 (5,800 tons in 65,585,865 US\$), while the lowest weight and its cost was found in the year 2011 (2,712 tons in $31,121,863$ US\$) (Figure 2).

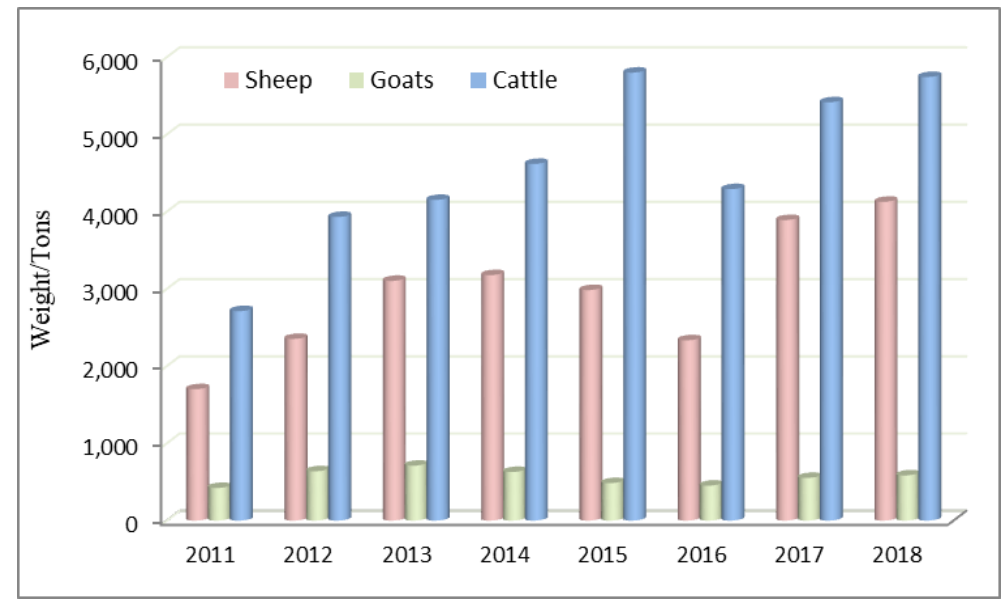

Fig (2): The weight of slaughtered animal distributed on years and hosts

\section{The number, infection rate, weight and cost} of different lost (infected) organs in slaughtered sheep:

From the total of 80,834 infected sheep, the more infected organ was liver then lungs then (Liver and lungs) then kidney and finally spleen $(53.35 \%, 32.68 \%, 12.59 \%, 1.08 \%$ and $0.3 \%$ respectively) (Table 1 and Figure 3). The lost amounts of liver, lungs, (Liver and lungs), kidney and spleen of sheep were 62.233 tons, 10.653 tons, 18.731 tons, 0.218 tons and 0.071 tons respectively, and lost costs of $(658,298$ US\$, 16,803 US\$, 113,709 US\$, 2,223 US\$ and 729 US\$). As a result of the above, the total lost from all organs of sheep was 91.905 tons with a cost of 791,762 US\$ (Table 1).

Table (1): The total loss from contamination organs in sheep

\begin{tabular}{ccccccc}
\hline & Liver & Liver \& Lungs & Lungs & Spleen & Kidney & Total \\
\hline Infected No. & 43,122 & 10,179 & 26,419 & 245 & 869 & 80,834 \\
Infection rate & $53.35 \%$ & $12.59 \%$ & $32.68 \%$ & $0.3 \%$ & $1.08 \%$ & $100 \%$ \\
Tons & 62.233 & 18.731 & 10.653 & 0.071 & 0.218 & 91.905 \\
Ton Price\$ & $10,600 \pm 119$ & $6,077 \pm 68$ & $1,555 \pm 17.3$ & $10,241 \pm 115$ & $10,191 \pm 111$ & 791,762 \\
Total\$ & 658,298 & 113,709 & 16,803 & 729 & 2,223 &
\end{tabular}


4. The number, infection rate, weight and cost of diffirnt lost (infected) organs in slaughtered goats:

From the total of 7,561 infected goats, the more infected organ was liver then lungs then (Liver and lungs) then kidney and spleen (53.29\%, 33.17\%, $12.21 \%, 1.2 \%$ and $0.13 \%$ respectively) (Table 2 and Figure 3). with lost amounts of (5.574 tons, 0.985 tons, 1.644 tons, 0.024 tons and 0.003 tons respectively) and lost cost of (59,025 US\$, 1,526 US\$, 9,970 US\$, 246 US\$ and 31 US\$). As a result, the total lost from all goats was 8.229 tons with a cost of 70,799 US\$ (Table 2).

Table (2): The total loss from contamination organs in goats

\begin{tabular}{|c|c|c|c|c|c|c|}
\hline & Liver & Liver \& Lungs & Lungs & Spleen & Kidney & Total \\
\hline Infected No. & 4,029 & 923 & 2,508 & 10 & 91 & 7,561 \\
\hline Infection rate & $53.29 \%$ & $12.21 \%$ & $33.17 \%$ & $0.13 \%$ & $1.2 \%$ & $100 \%$ \\
\hline Tons & 5.574 & 1.644 & 0.985 & 0.003 & 0.024 & 8.229 \\
\hline Ton Price\$ & $10,597 \pm 116$ & $6,081 \pm 68$ & $1,565 \pm 17.1$ & $10,307 \pm 112$ & $10,257 \pm 115$ & \\
\hline Total\$ & 59,025 & 9,970 & 1,526 & 31 & 246 & 70,799 \\
\hline
\end{tabular}

5. The number, infection rate, weight and cost of diffirnt lost (infected) organs in slaughtered cattle:

From the total of 10.524 infected cattle, the more infected organ was lungs then liver then (Liver and lungs) then kidney and finally spleen $(48.25 \%, 31.45 \%, 18.27 \%, 1.97 \%$ and $0.24 \%$ respectively) (Table 3 and Figure 3) with lost amounts of (10.374 tons, 22.036 tons, 16.87 tons, 0.247 tons and 0.034 tons respectively) and lost costs of (16,189 US\$, 234,245 US\$, 102,825 US\$, 2,580 US\$ and 357 US\$). As a result, the total lost from all organs of cattle was 49.561 tons with a cost of 356,196 US\$ (Table 3).

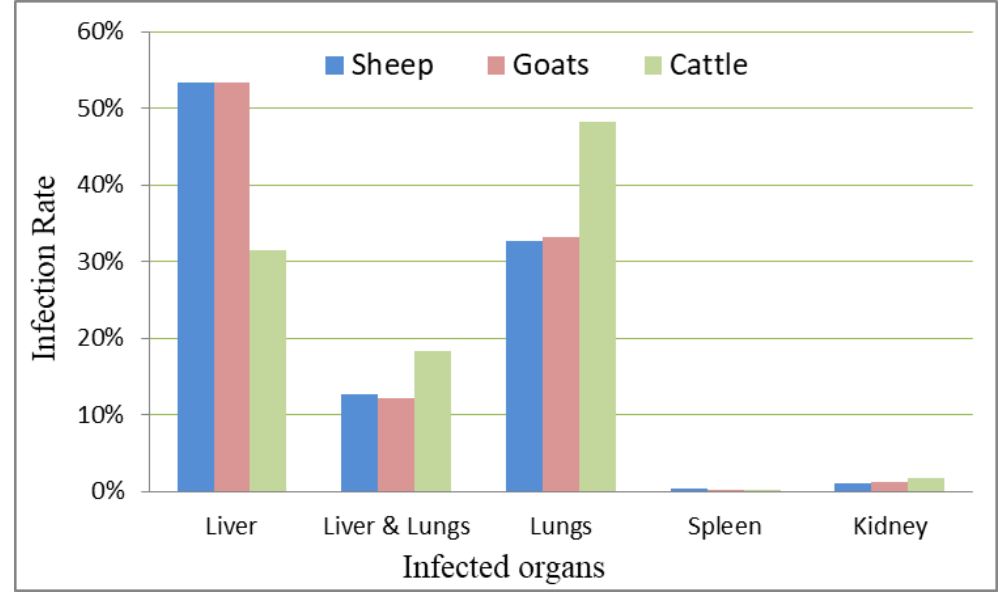

Fig (3): The infection rates in different organs of intermediat hosts.

Table (3): The total loss from contamination organs in cattle 


\begin{tabular}{ccccccc}
\hline & Liver & Liver \& Lungs & Lungs & Spleen & Kidney & Total \\
\hline Infected No. & 3,310 & 1,923 & 5,078 & 25 & 188 & 10,524 \\
Infection rate & $31.45 \%$ & $18.27 \%$ & $48.25 \%$ & $0.24 \%$ & $1.79 \%$ & $100 \%$ \\
Tons & 22.036 & 16.87 & 10.374 & 0.034 & 0.247 & 49.561 \\
Ton Price\$ & $10,652 \pm 117$ & $6,114 \pm 66$ & $1,575 \pm 16.8$ & $10,450 \pm 117$ & $10,400 \pm 116$ & 356,196
\end{tabular}

6. The over all numbers, infection rates, weights and costs of diffirnt lost (infected) organs of all slaughtered animals.

As a total, 98,919 infected animals were found during the study period, the more infected organ was liver then lungs then (Liver and lungs) then kidney and spleen $(51.01 \%, 34.38 \%$, $13.17 \%, 1.16 \%$ and $0.28 \%$ respectively) (Figure 4 ), these results take the same mode of data published by (Borji, Azizzadeh et al. 2012) and (Getaw, Beyene et al. 2010).

The lost amounts of liver, lungs, (Liver and lungs), kidney and spleen of sheep were 89.843 tons, 22.012 tons, 37.245 tons, 0.488 tons and 0.107 tons respectively, and lost costs of (951,568 US\$, 34,519 US\$, 226,504 US\$, 5,048 US\$ and 1,117 US\$). As a result, the total lost from all organs of all infected animals was 149.695 tons with a cost of $1,218,757$ US\$.

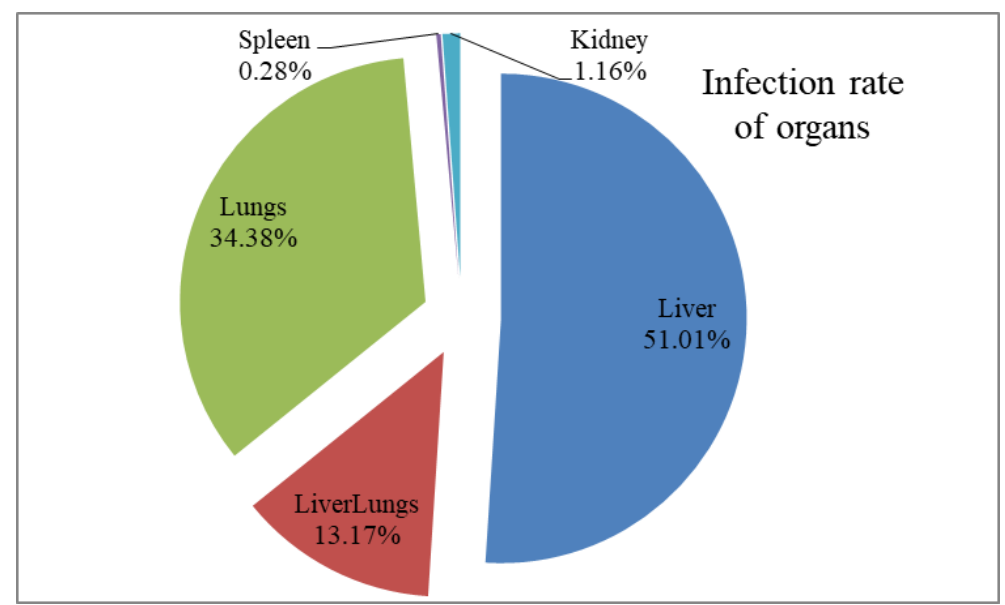

Fig (4): The infection rates in different organs of intermediat hosts.

\section{ACKNOWLEDGMENT}

I am thankful to the Duhok veterinary directorate and all their staff for assistance in obtaining data and CE samples from abattoirs belong to their directorate.

\section{REFERENCES}

Abdullah, A. M. (2010). Epidemiological, Comparative Enzymatic and Total Protein content of Hydatid cyst of Ecchinococcus granulosus isolated from Sheep and Goats in
Duhok province, Kurdistan Region of Iraq. M. Sc., University of Duhok.

AL-Bosely, A. R. I. (2014). Studies on epidemiology of hydatid cysts isolated from different intermediate hosts in zakho, Duhok province, Kurdistan region, Iraq. M.Sc., University of Zakho.

Battelli, G. (2004). "Socio-economic impact of cystic echinococcosis and of its control: some data and considerations." Parassitologia 46(4): 359-362.

Benner, C., H. Carabin, L. P. Sanchez-Serrano, C. M. Budke and D. Carmena (2010). "Analysis of the 
economic impact of cystic echinococcosis in Spain." Bull World Health Organ 88(1): 49-57.

Borji, H., M. Azizzadeh and M. Kamelli (2012). "A retrospective study of abattoir condemnation due to parasitic infections: economic importance in Ahwaz, southwestern Iran." J Parasitol 98(5): 954-957.

Budke, C. M., P. Deplazes and P. R. Torgerson (2006). "Global socioeconomic impact of cystic echinococcosis." Emerg Infect Dis 12(2): 296303.

Budke, C. M., Q. Jiamin, W. Qian and P. R. Torgerson (2005). "Economic effects of echinococcosis in a disease-endemic region of the Tibetan Plateau." Am J Trop Med Hyg 73(1): 2-10.

Budke, C. M., A. C. White Jr and H. H. Garcia (2009). "Zoonotic larval cestode infections: neglected, neglected tropical diseases?" PLoS neglected tropical diseases 3(2): e319.

Eckert, J. and P. Deplazes (2004). "Biological, epidemiological, and clinical aspects of echinococcosis, a zoonosis of increasing concern." Clin Microbiol Rev 17(1): 107-135.

Getaw, A., D. Beyene, D. Ayana, B. Megersa and F. Abunna (2010). "Hydatidosis: prevalence and its economic importance in ruminants slaughtered at Adama municipal abattoir, Central Oromia, Ethiopia." Acta tropica 113(3): 221-225.

Ghaffar, N. M. (2008). Prevalence of hydatidosis in livestock slaughtered at Duhok abattoir of Kurdistan Region of Iraq, Duhok.

Hama, A. A. (2013). Epidemiological study and molecular characterization of Echinococcus granulosus in Suleimani province KurdistanIraq. PhD. Thesis, Faculty of Science, Zakho University.

Hassan, Z. I. (2017). Epidemiological Study and Molecular Characterization of Echinococcus granulosus in Erbil Province, Kurdistan RegionIraq, Ph.D. thesis, Faculty of Science, University of Zakho.

Herrero, M. and P. K. Thornton (2013). "Livestock and global change: emerging issues for sustainable food systems." Proceedings of the National Academy of Sciences 110(52): 2087820881.

Houin, R. (1998). Current situation of echinococcosis in Europe. Symposium on Environmental Adaptation of Echinococcosis, (pp. 18-20). Hakkaido University Sapparo, Japan.
Hussein, J. N. and A. A. Meerkhan (2019). "The Incidence Of Intestinal Parasites Among Children In Hivi Pediatric Hospital, Duhok, Iraq." Science Journal of University of Zakho 7(1): 1-4.

Jimenez, S., A. Perez, H. Gil, P. Schantz, E. Ramalle and R. Juste (2002). "Progress in control of cystic echinococcosis in La Rioja, Spain: decline in infection prevalences in human and animal hosts and economic costs and benefits." Acta Trop 83(3): 213-221.

Kebede, W., A. Hagos, Z. Girma and F. Lobago (2009). "Echinococcosis/hydatidosis: its prevalence, economic and public health significance in Tigray region, North Ethiopia." Trop Anim Health Prod 41(6): 865-871.

Majorowski, M. M., H. Carabin, M. Kilani and A. Bensalah (2005). "Echinococcosis in Tunisia: a cost analysis." Trans R Soc Trop Med Hyg 99(4): 268-278.

Mantovani, A. (1980). Information on echinococcosis/hydatidosis in Italy. WHO European Meeting on hydatidosis control (Mediterranean Countries). Document ICP/BVM.

McManus, D. (2003). "Zhang w, Li J, Bartley PB." Echinococcosis. Lancet 362: 1295-1304.

Meerkhan, A. A. and A. M. Abdullah (2012). The epidemiology of hydatidosis in different slaughtered animals in Duhok abattoir, Kurdistan Region of Iraq. Second international conference. Bali (Indonesia).

Meerkhan, A. A. and W. M. Mero (2018). "Prevalence of Echinococcus Granulosus in Different Intermediate Hosts in Duhok Province, Kurdistan Region, Iraq." Science Journal of University of Zakho 6(1): 1-3.

Moro, P. L., C. M. Budke, P. M. Schantz, J. Vasquez, S. J. Santivanez and J. Villavicencio (2011). "Economic impact of cystic echinococcosis in peru." PLoS Negl Trop Dis 5(5): e1179.

Pradere, J. (2014). "Links between livestock production, the environment and sustainable development." Revue scientifique et technique (International Office of Epizootics) 33(3): 765781.

Randolph, T. F., E. Schelling, D. Grace, C. F. Nicholson, J. Leroy, D. Cole, M. Demment, A. Omore, J. Zinsstag and M. Ruel (2007). "Invited review: Role of livestock in human nutrition and health for poverty reduction in developing countries." Journal of animal science 85(11): 2788-2800. 
Saeed, I., C. Kapel, L. Saida, L. Willingham and P. Nansen (2000). "Epidemiology of Echinococcus granulosus in Arbil province, northern Iraq, 1990-1998." Journal of helminthology 74(01): 83-88.

Sarı̈zkan, S. and C. Yalçın (2009). "Estimating the production losses due to cystic echinococcosis in ruminants in Turkey." Veterinary parasitology 163(4): 330-334.

Singh, B. B., N. K. Dhand, S. Ghatak and J. P. Gill (2014). "Economic losses due to cystic echinococcosis in India: Need for urgent action to control the disease." Prev Vet Med 113(1): 1-12.

Torgerson, P. R. (2003). "Economic effects of echinococcosis." Acta Trop 85(2): 113-118.

Torgerson, P. R., C. Carmona and R. Bonifacino (2000). "Estimating the economic effects of cystic echinococcosis: Uruguay, a developing country with upper-middle income." Ann Trop Med Parasitol 94(7): 703-713.
Torgerson, P. R., P. M. Dowling and M. N. AboShehada (2001). "Estimating the economic effects of cystic echinococcosis. Part 3: Jordan, a developing country with lower-middle income." Ann Trop Med Parasitol 95(6): 595-603.

WHO, W. H. O. (2007). Global plan to combat neglected tropical diseases 2008-2015, Geneva: World Health Organization.

Yang, F. (1992). "A study of domestic animals with Echinococcus infection in Qinghai Province and suggestions for control." Qinghai Xumu Shouyi Zazhi 22: 22-25.

Yang, Y. R., G. M. Williams, P. S. Craig and D. P. McManus (2010). "Impact of increased economic burden due to human echinococcosis in an underdeveloped rural community of the People's Republic of China." PLoS Negl Trop Dis 4(9).

Yemane, G. (1990). Preliminary study of echinococcosis in ruminants slaughtered at Adama abattoir. DVM Thesis, Addis Ababa University, Faculty of Veterinary Medicinea. 